\title{
Authentic Learning Pada Mata Kuliah Produksi Media Cetak
}

\author{
Endah Resnandari Puji Astuti ${ }^{1}$ dan Muh. Husein Baysha ${ }^{2}$ \\ endahresnandaripujiastuti@gmail.com
}

\begin{abstract}
ABSTRAK
Pembelajaran yang diberikan kepada mahasiswa seharusnya perlu memperhatikan dan mempertimbangkan kebermaknaan pengalaman. Salah satu pembelajaran yang dapat dipilih dalam memberikan pengalaman yang bermakna kepada mahasiswa adalah authentic learning atau pembelajaran autentik. Tujuan penelitian pada mata kuliah produksi media cetak ini adalah; (1) mendeskripsikan pelaksanaan authentic learning, (2) mengetahui ketercapaian hasil pelaksanaan authentic learning, (3) mengidentifikasi kendala pelaksanaan authentic learning. Metode yang dipakai dalam penelitian ini adalah deskriptif-kualitatif. Penentuan sumber data menggunakan metode sampel bertujuan (purposive sampling). Keabsahan data yang diperoleh dari penelitian ini maka digunakan data triangulation, dimana peneliti menggunakan beberapa sumber data yang sama. Metode pengumpulan data yang digunakan adalah observasi, wawancara, dan dokumen. Teknik analisis yang digunakan dalam penelitian ini melalui cara; (1) reduksi data, yaitu merupakan proses pemilihan, pemusatan perhatian pada penyederhanaan, pengabstrakan dan transformasi data kasar yang diperoleh di lapangan, (2) penyajian data, yaitu dengan menyajikan berbagai informasi yang diseleksi dalam rangka penarikan kesimpulan, (3) verifikasi data. Penelitian ini diharapkan dapat mengidentifikasi pelaksanaan, ketercapaian, dan kendala penerapan authentic learning pada mata kuliah produksi media cetak pembelajaran. Luaran hasil penelitian ini adalah publikasi ilmiah hasil penelitian dalam jurnal ber-ISSN dan prosiding pada seminar nasonal. Hasil penelitian ini yaitu terlaksananya pembelajaran authentic dengan proyek pembuatan booklet pembelajaran oleh mahasiswa Program Studi Teknologi Pendidikan. Manfaat yang diperoleh dari pelaksanaan pembelajaran authentic yaitu 1) mahasiswa dapat belajar secara aktif; 2) mahasiswa memiliki pengalaman belajar langsung/nyata; 3) mahasiswa memiliki pengalaman belajar dalam tim/kelompok; 4) mahasiswa dapat secara langsung terlibat dalam menyelesaikan tugas-tugas kompleks yang membutuhkan kemampuan berfikir tinggi; 5) mahasiswa dapat mengembangkan kemampuan bersosialisasi dan diskusi dalam tim maupun antar tim; 6) mahasiswa belajar disiplin dan bertanggung jawab terhadap tugas.
\end{abstract}

Kata kunci: authentic learning, produksi media cetak pembelajaran

\section{PENDAHULUAN}

Pembelajaran yang diberikan kepada mahasiswa seharusnya perlu memperhatikan dan mempertimbangkan kebermaknaan pengalaman. Hal ini disebabkan karena melalui pengalaman secara langsung, mahasiswa akan mengingat lebih lama apa yang dipelajari. Mahasiswa perlu memperoleh bekal pengalaman yang bermakna bagi kehidupannya kelak karena perkembangan teknologi dan informasi akan menjadikan kehidupan banyak permasalahan yang menuntut pemecahan secepat mungkin.

Sebagai usaha untuk memberikan pengalaman yang bermakna kepada mahasiswa, perlu adanya pembelajaran dengan strategi dan pendekatan pembelajaran yang tepat. Salah satu pembelajaran yang dapat dipilih dalam memberikan pengalaman yang bermakna kepa mahasiswa adalah authentic learning atau pembelajaran autentik. Pembelajaran otentik (authentic learning) adalah sebuah pendekatan pembelajaran yang memungkinkan mahasiswa menggali, mendiskusikan, dan membangun secara bermakna konsep-konsep dan hubungan-hubungan, yang melibatkan masalah nyata dan proyek yang relevan dengan mahasiswa (Donovan dalam Denhere Christmas, 2014:52).

Dalam mata kuliah produksi media cetak pembelajaran di Program studi Teknologi Pendidikan, pembelajaran autentik dapat diterapkan untuk memperoleh pengalaman belajar yang nyata. Melalui pembelajaran autentik mahasiswa akan dapat mengembangkan keterampilan berpikir melalui pemecahan ma- 
salah dalam kehidupan nyata secara bekerja sama, baik dalam pasang-pasangan maupun kelompok mengenai pengembangan produksi media cetak pendidikan. Selain itu, mahasiswa juga dituntut untuk belajar bertanggung jawab dan belajar mandiri melalui bimbingan, arahan, dorongan untuk mengajukan pertanyaan, mencari penyelesaian terhadap permasalahan nyata yang dihadapi, dan belajar menyelesaikan tugas-tugas secara mandiri untuk kehidupannya kelak.

Dalam mata kuliah produksi media cetak ini, pembelajaran autetik yang akan diterapkan adalah melalui tugas proyek merancang media pembelajaran inovatif. Mahasiswa akan dibagi ke dalam beberapa kelompom untuk merencanakan, menganalisis, membuat dan mendesain media pembelajaran, mendeskripsikan, mempresentasikan hingga tahap melakukan evaluasi. Peran dosen yaitu sebagai motivator, fasilitator, dan mengarahkan kegiatan proyek yang akan dilakukan mahasiswa.

Authentik learning (pebelajaran au-
tentik) adalah sebuah pendekatan pembelajaran yang memungkinkan peserta didik menggali, mendiskusikan, dan membangun secara bermakna konsep-konsep dan hubungan-hubungan, yang melibatkan masalah nyata dan proyek yang relevan dengan peserta didik. Istilah 'otentik' berarti asli, sejati, dan nyata. Pembelajaran ini dapat digunakan untuk peserta didik pada semua tingkatan kelas, maupun peserta didik dengan berbagai macam tingkat kemampuan (Denhere Christmas, 2014:56)

Authentic learning memberikan kesempatan kepada mahasiswa untuk mengeksplorasi, berdiskusi secara mendalam, membentuk konsep dan hubungan dalam konteks yang melibatkan permasalahan dunia nyata dan mengembangkan proyek-proyek yang relevan dengan peserta didik. Dalam pembelajaran autentik peserta didik harus terlibat dalam masalah belajar nyata. Hal ini akan mendorong dan memberikan kesempatan bagi mereka untuk membuat koneksi langsung antara masalah yang dihadapi degan material baru yang sedang dipelajari. Mahasiswa dapat melakukan analisis dan diskusi secara mendalam untuk menemukan solusi dari permasalahan yang ada.
Dijelaskan bahwa pembelajaran autentik merupakan salah satu terminology dari pembelajaran berbasis masalah yang merupakan pola penyajian pembelajaran dalam bentuk permasalahan yang nyata/autentik ( $a u$ thentic) dan bermakna agar memudahkan peserta didik melakukan penyelidikan dan inkuiri (Milan Rianto, 2006:22).

Pengalaman belajar otentik memiliki beberapa elemen penting yaitu sebagai berikut: (1) real world relevance, (2) ill-defined nature of the learning task, (3) incorporation into the activity of several complex tasks that require a sustained period of time to be fulfilled, (4) opportunity for the students to explore the task from different perspectives, (5) opportunity to collaborate, (6) opportunity to reflect, (7) activities can be integrated across different subjects, (8) assessment is seamlessly integrated with the task, (9) outcome of the activity is a polished product, and (10) diversity of outcomes is possible. (Herrington, Oliver, and Reeves dalam Larisa Nikitina, 2011:35). Terjemahan beberapa elemen penting dari pembelajaran autentik yaitu: (1) relevansi dunia nyata, (2) sifat tidak jelas dari tugas belajar, (3) penggabungan ke dalam aktivitas beberapa tugas-tugas kompleks yang memerlukan berkelanjutan periode waktu yang harus dipenuhi, (4) kesempatan bagi mahasiswa untuk mengeksplorasi tugas dari perspektif yang berbeda, (5) kesempatan untuk berkolaborasi, (6) kesempatan untuk melakukan refleksi, (7) kegiatan dapat diintegrasikan ke seluruh mata pelajaran yang berbeda, (8) penilaian dapat terintegrasi dengan tugas, (9) hasil dari kegiatan ini adalah berupa produk, dan (10) memungkinkan untuk keragaman hasil.

Sejalan dengan penjelasan di atas, pendapat yang tidak jauh berbeda dijelaskan sebagai berikut:

The four themes supporting authentic learning, identified through the content analysis of forty-five articles describing authentic learning in different disciplines are: 1) the activity involves real-world problems that mimic the work of professionals in the discipline with presentation of findings to audiences beyond the classroom; 2) open-ended inquiry, thinking skills, and metacognition are addressed; 3) students engage in discourse and social 
learning in a community of learners; and 4) students are empowered through choice to direct their own learning in relevant project work. (Audrey C. Rule, 2006:2)

Keempat tema pendukung pembelajaran autentik, diidentifikasi melalui konten analisis empat puluh lima artikel yang menjelaskan pembelajaran otentik dalam berbagai disiplin ilmu yaitu: 1) aktivitas melibatkan masalah dunia nyata yang meniru karya profesional dalam disiplin dengan presentasi temuan kepada khalayak di luar ruang kelas; 2) penyelidikan terbuka, keterampilan berpikir, dan menunjukkan metakognisi; 3) mahasiswa terlibat dalam wacana dan pembelajaran sosial dalam komunitas peserta didik; dan 4) mahasiswa diberdayakan melalui pilihan untuk mengarahkan pembelajaran mereka sendiri dalam pekerjaan proyek yang relevan.

Mata kuliah produksi media cetak pembelajaran merupakan salah satu mata kuliah wajib yang harus diikuti oleh mahasiswa Prodi Teknologi Pendidikan. Mata kuliah produksi media cetak juga merupakan kelompok mata kuliah keahlian berkarya yang menuntut mahasiswa untuk dapat menciptakan karya tertentu sesuai dengan mata kuliah tersebut (Astuti dan Baysha, 2017 :43). Oleh karena itu, diperlukan metode pembelajaran yang tepat agar mahasiswa dapat benar-benar menghasilkan karya produktif yang inovatif. Salah satu metode pembelajaran yang dapat digunakan yaitu dengan menerapkan pembelajaran autehentic learning pada mata kuliah produksi media cetak .

Pelaksanaan autehentic learning pada mata kuliah produksi media cetak pembelajaran dapat mengikuti tahapan atau sintaks sebagai berikut:

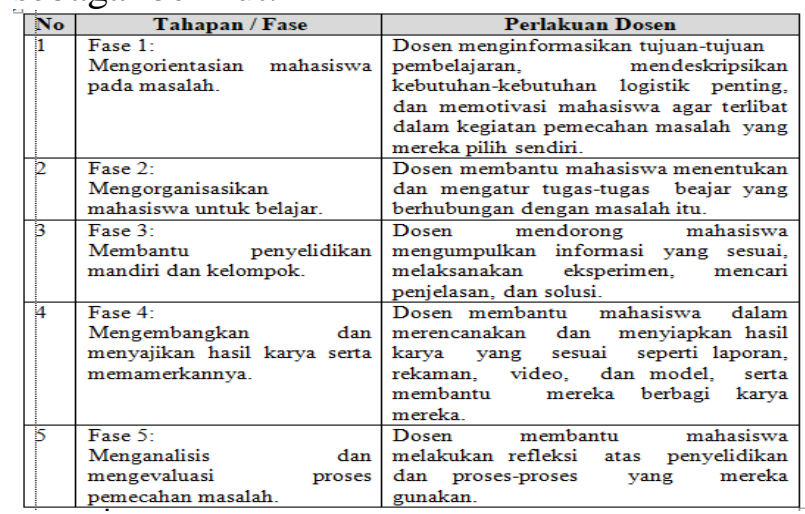

Tabel 1. Sintaks Pelaksanaan Autehentic Learning

\section{METODE PENELITIAN}

Penelitian ini merupakan penelitian kualitatif dengan pendekatan deskriptif. Menurut Bogdan dan Taylor dalam Lexy J. Moleong (2010: 4), Metodologi kualitatif adalah prosedur yang dihasilkan data deskriptif berupa kata tertulis atau lisan dari orang-orang dan perilaku yang dapat diamati. Tujuan penelitian ini mendeskripsikan penerapan authentic learning pada mata kuliah produksi media cetak pembelajaran. Penelitian ini rencananya dilaksanakan selama enam (6) bulan dan lokasi penelitian berada di Prodi Teknologi Pendidikan IKIP Mataram yang beralamat di Jl. Pemda No. 59-A Mataram. Teknik pengumpulan data penelitian ini meliputi metode wawancara (interview), studi dokumen (documentary study), dan observasi (observation).

Validitas data penelitian ini menggunakan data triangulation, dimana informasi dari berbagai sumber diseleksi. Data-data yang tidak konsisten dikonfirmasikan ulang dan observasi. Untuk menetapkan keabsahan (trustworthiness) data diperlukan teknik pemeriksaan. Ada empat macam kriteria yang digunakan, yaitu derajat kepercayaan (credibility), keteralihan (transferability), ketergantungan (debendability), dan kepastian (confirmability). Metode analisis yang digunakan pada penelitian ini adalah model analisis interaktif mengalir. Secara garis besar analisis interaktif mengalir terdiri dari tiga alur kegiatan yang terjadi secara bersamaan yaitu reduksi data, penyajian data dan penarikan kesimpulan atau verifikasi.

Penelitian dilaksanakan pada Program Studi Teknologi Pendidikan, Fakultas Ilmu Pendidikan, IKIP Mataram. Alamat tempat penelitian yaitu Jalan Pemuda No 59 A Mataram, Nusa Tenggara Barat. Penelitian ini dibatasi pada pembelajaran mata kuliah computer dan media pembelajaran.

Teknik pengumpulan data penelitian ini meliputi metode wawancara (interview), studi dokumen (documentary study), dan observasi (observation).

1. Wawancara (Interview)

Menurut Lexy J. Moleong (2010: 186) wawancara adalah percakapan dengan maksud tertentu. Percakapan itu dilakukan 
oleh dua pihak, yaitu pewawancara (interviwer) yang mengajukan pertanyaan dan yang diwawancarai (interviewer) yang memberikan jawaban atas pertanyaan. Wawancara dilakukan dengan informan yang menguasai permasalahan dan dapat memberikan informasi yang lengkap kaitannya pelaksanaan authentic learning pada mata kuliah produksi media cetak pembelajaran. Wawancara penelitian ini dilakukan terhadap beberapa mahasiswa semester $\mathrm{V}$ yang mengikuti mata kuliah produksi media cetak pembelajaran. Wawancara ini untuk menggali informasi terkait pelaksanaan project based learning dalam mengembangkan soft skill mahasiswa.

2. Studi Dokumen (documentary study)

Studi dokumen penelitian ini dilakukan dengan mengumpulkan data, berupa dokumen kaitannya perencanaan, pelaksanaan, dan produk hasil authentic learning mata kuliah produksi media cetak pembelajaran. Mendokumentasikan pelaksanaan kegiatan authentic learning mahasiswa. Selain itu, terkait dengan dokumen produk authentic learning mata kuliah produksi media cetak pembelajaran.

\section{Observasi (observation)}

Eko Putro Widoyoko (2012:46) menjelaskan bahwa observasi dapat diartikan sebagai pengamatan atau pencatatan secara sistematik terhadap unsur-unsur yang nampak dalam suatu gejala pada objek penelitian. Penelitian ini melaksanakan jenis observasi sistematik dimana pedoman observasi telah disiapkan dan dirancang secara sistematik oleh peneliti. Peneliti akan menyiapkan pedoman pengamatan secara detail daftar cek (check list) maupun catatatan observasi lapangan (filenote observation).

Menurut Patton dalam Iqbal Hasan (2010: 29) menjelaskan bahwa analisis data adalah proses mengatur urutan data, mengorganisasikannya ke dalam suatu pola, kategori, dan satuan uraian dasar. Dalam penelitian ini, proses menganalisis data dimulai dengan mengumpulkan semua data dari studi dokumen, observasi dan wawancara. Metode analisis yang digunakan pada penelitian ini adalah model analisis interaktif mengalir, yaitu model analisis yang menyatu dengan proses pengumpulan data dalam suatu siklus. Secara garis besar analisis interaktif mengalir terdiri dari tiga alur kegiatan yang terjadi secara bersamaan yaitu reduksi data, penyajian data dan penarikan kesimpulan atau verifikasi.

\section{HASIL DAN PEMBAHASAN Hasil Penelitian}

Penelitian ini dilaksanakan di IKIP Mataram dengan sasaran penelitian adalah mahasiswa Program Studi Teknologi Pendidikan semester 5 (lima) tahun pelajaran 2017/2018. Tujuan penelitian ini yaitu untuk mendeskrpsikan pelaksanaan authentic learning pada mata kuliah produksi media cetak. Mata kuliah produksi media cetak merupakan salah satu matakuliah yang menuntut adanya suatu produk tertentu yang dihasilkan oleh mahasiswa, dimana produk tersebut merupakan produk media hasil cetak. Pada semester ini, mahasiswa Teknologi Pendidikan diarahkan untuk menghasilkan produk media cetak berupa booklet pembelajaran. Booklet adalah buku kecil yang berfungsi untuk menyampaikan pesan-pesan atau informasi-informasi.

Sebagaimana hasil wawancara terhadap dosesn pengampu mata kuliah produksi media cetak yaitu Zinnurain menjelaskan bahwa booklet dapat digunakan sebagai media pembelajaran selama sajiannya diturunkan dari kompetensi dasar yang harus dikuasai oleh siswa. Booklet merupakan salah satu media cetak untuk menyampaikan materi dalam bentuk ringkasan dan gambar yang menarik, dimana dapat digunakan sebagai media untuk memahami materi pembelajaran, sekaligus dapat memberikan minat serta kesenangan dalam belajar. Hal ini disebabkan karena desain booklet yang menarik, menyajikan materi yang lebih singkat disertai dengan gambargambar berwarna.

Pelaksanaan authentic learning dalam pembuatan booklet pembelajaran pada mata kuliah produksi media cetak adalah sebagai berikut:

1. Mengorientasian mahasiswa pada masalah

Pada tahap ini, Dosen menginformasikan tujuan-tujuan pembelajaran, mendeskripsikan kebutuhan-kebutuhan penting, dan memotivasi mahasiswa agar terlibat dalam kegiatan pemecahan masalah yang mereka pilih sendiri. Dosen 
menyampaikan tujuan dalam membuat produk media cetak berupa booklet pembelajaran, perencenaan desain, pemilihan mata pelajaran, tema/topik yang diturunkan dari standar kompetensi mata pelajaran, serta pencetakan booklet.

2. Mengorganisasikan mahasiswa untuk belajar

Pada tahap ini, dosen membantu mahasiswa menentukan dan mengatur tugas-tugas beajar yang berhubungan dengan pembuatan booklet. Pertamatama dosen mengarahkan mahasiswa untuk membuat kelompok-kelompok kecil yang terdiri dari 4-5 orang. Setiap kelompok membuat booklet pembelajaran dengan satu tema tertentu, dimana tema tersebut diturunkan dari standar kompetensi sesuai dengan kurikulum yang berlaku. Pada kelas semester lima tersebut ada 7 kelompok yang setiap kelompok terdiri dari 5 mahasiswa, ini berarti ada 7 tema yang dikembangkan menjadi booklet pembelajaran.

3. Membantu penyelidikan mandiri dan kelompok

Pada tahap ini, mahasiswa dibimbing untuk mengumpulkan informasi berkaitan dengan tema boklet yang dikembangkan oleh masing-masing kelompok. Dalam mengumpulkan informasi, mahasiswa juga mencari bahan sebagai bahan isi booklet pembelajaran yang dikembangkan.

Pada setiap tahapan yang dilakukan, dosen bertanggung jwab untuk memantau kegiatan mahasiswa selama menyelesaikan proyek. Pemantauan dilakukan dengan cara memfasilitasi mahasiswa pada setiap proses. Dengan kata lain dosen berperan menjadi mentor bagi aktivitas mahasiswa. Agar mempermudah proses pemantauan, dibuat sebuah rubrik yang dapat merekam keseluruhan kegiatan yang penting.

Berikut adalah dekripsi kegiatan dalam penyelesaian project booklet berbasis authentic learning:
Table 2. Deskrpsi Kegiatan Project Booklet

\begin{tabular}{|c|c|c|}
\hline No & Deskripsi Kegiatan & Petugas \\
\hline 1 & Menyusun Tim/kelompole & Mahasiswa dengan dibimbing dosen \\
\hline 2 & $\begin{array}{l}\text { Menentukan kelas, standar koopetensi, } \\
\text { tema, dan rencana desain }\end{array}$ & Semua anggota kelompok \\
\hline 3 & $\begin{array}{l}\text { Mengumpulkan informasi dan bahan isian } \\
\text { booklet }\end{array}$ & Semua anggota kelompok \\
\hline 4 & Menyeleksi informasi dan materi booklet & $\begin{array}{l}\text { Anggota kelompok berdiasarkan } \\
\text { pembagian tugas }\end{array}$ \\
\hline 5 & $\begin{array}{l}\text { Konsultasi dengan dosen terkait kegiatan } \\
\text { yang telah dilakukan }\end{array}$ & Semua anggota kelompok \\
\hline 6 & $\begin{array}{l}\text { Proses Desain booklet dengan aplikasi in } \\
\text { design }\end{array}$ & $\begin{array}{l}\text { Anggota kelompok berćasarkan } \\
\text { pembagian tugas }\end{array}$ \\
\hline 7 & $\begin{array}{l}\text { Konsultasi dengan dosen terkait kegiatan } \\
\text { yang telah dilakukan }\end{array}$ & Semua anggota kelompok \\
\hline 8 & Revisi desain & \\
\hline 9 & Melakukan perencanaan cetak booklet & Semua anggota kelompok \\
\hline 10 & Mencetak booklet & Semua anggoota kelompok \\
\hline 11 & Melakukan presentasi isi booklet & Semua anggota kelompok \\
\hline 12 & $\begin{array}{l}\text { Mencatat komentar dan saran dari teman } \\
\text { teman dan dosen }\end{array}$ & Semua anggota kelompok \\
\hline
\end{tabular}

4. Mengembangkan dan menyajikan hasil karya serta memamerkannya

Pada tahap ini, dosen membantu mahasiswa dalam merencanakan dan menyiapkan hasil karya yang sesuai seperti laporan, rekaman, video, dan model, serta membantu mereka berbagi karya mereka. Disini mahasiswa akan mempresentasikan hasil karya booklet yang telah selesai dikerjakan. Presentasi mencakup sasaran penggunaan media booklet pembelajaran, alasan pemilihan tema, isi booklet, desain booklet, serta kendala dalam pembuatan booklet tersebut. Dalam pelaksanaan presentasi ini, mahasiswa akan mendapat masukan dari dosen dan kelompok lainnya.

5. Menganalisis dan mengevaluasi proses pemecahan masalah

Dalam tahap ini dosen memberikan penilaian terhadap kinerja mahasiswa dalam pembuatan booklet pembelajaran. Dosen juga membantu mahasiswa melakukan refleksi atas penyelidikan dan proses-proses yang mereka gunakan. Agar mempermudah dalam proses penilaian terhadap kinerja mahasiswa, maka dinuat rubrik penilaian sebagai berikut:

\begin{tabular}{|l|l|l|l|}
\hline$N_{0}$ & \multicolumn{1}{|c|}{ Kategori } & Sesuai & Tidak sesuai \\
\hline 1 & $\begin{array}{l}\text { Pemilihan tema berdasarkan standar } \\
\text { kompetensi pembelajaran }\end{array}$ & & \\
\hline 2 & Kesesuaian Isi booklet dengan tema & & \\
\hline 3 & Desain booklet & & \\
\hline 4 & $\begin{array}{l}\text { Komposisi tulisan dan gambar, komposisi } \\
\text { wama }\end{array}$ & & \\
\hline 5 & Ketepatan waktu pengumpulan laporan & & \\
\hline 5 & Kenjasama tim dalam praktek & & \\
\hline
\end{tabular}

Tabel 3. Rubrik Penilaian Proyek Booklet Pembelajaran 
Berdasarkan rubrik penilaian di atas, diperoleh hasil bahwa sebanyak $100 \%$ tim telah sesuai dalam memilih tema berdasarkan standar kompetensi pembelajaran di sekolah. Tema dan judul booklet yang dibuat oleh tujuh tim mahasiswa yaitu: 1) 18 cara merakit CPU; 2) Mengenal bagian-bagian tumbuhan; 3) sistem terjadinya hujan; 4) rantai makanan dan jaring-jaring makanan; 5) mengenal tata surya; 6) ciri-ciri makhluk hidup; 7) cara instal windows 10 dengan flashdisk. Semntara itu penilaian mengenai kesuesuaian antara tema dengan isi yaitu $100 \%$ sudah sesuai. Desain booklet $90 \%$ tim telah mendesain sesuai dengan tema. Untuk komposisi antara tulisan dan gambar sebanyak $90 \%$ tim telah membuat booklet pembelajaran dengan komposisi yang tepat sehingga memudahkan untuk dibaca, dipahami, dan lebih menarik. Untuk penilaian kerjasama dalam tim, sebanyak $80 \%$ telah dapat bekerjasama dengan baik dalam menyelesaikan proyek pembuatan booklet pembelajaran pada mata kuliah produksi media cetak. Berikut adalah gambar booklet mahasiswa teknologi pendidikan.

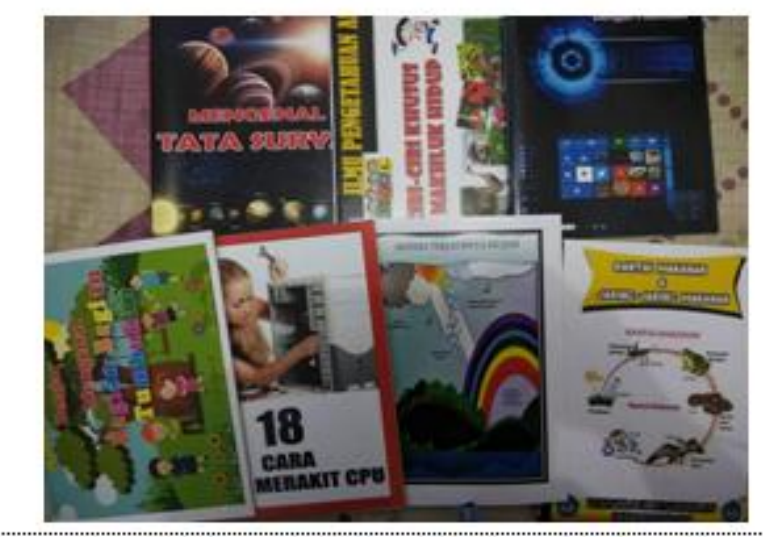

Gambar 1. Booklet Pembelajaran Mahasiswa

Pada tahap ini dosen bersama mahasiswa juga melakukan evaluasi dan refleksi terhadap hasil kinerja proyek booklet pembelajaran yang telah dilaksanakan oleh mahasiswa. Refleksi ini dilakukan baik secara individu maupun kelompok. Kegiatan refleksi dilakukan dengan mengemukakan berbagai kekurangan maupun kelebihan dari masingmasing kelompok sehingga dapat dijadikan pembelajaran bagi kegiatan selanjutnya baik bagi mahasiswa maupun dosen.

\section{Pembahasan}

Proses pembelajaran pada mata kuliah produksi media cetak mahasiswa semeJurnal Ilmiah Mandala Education ster lima program studi Teknologi Pendidikan tahun pelajaran 2017/2018 menggunakan authentic learning. Pembelajaran otentik (authentic learning) adalah sebuah pendekatan pembelajaran yang memungkinkan siswa menggali, mendiskusikan, dan membangun secara bermakna konsep-konsep dan hubunganhubungan, yang melibatkan masalah nyata dan proyek yang relevan dengan siswa.

Dalam pelaksanaan authentic learning pada mata kuliah produksi media cetak, mahasiswa diberi proyek untuk menyelesaikan permasalahan dalam pembuatan atau pengembangan media booklet pembelajaran. Media booklet dipilih karena booklet merupakan salah satu produk media yang berbetuk cetak. Booklet juga merupakan media pembelajaran yang menarik apabila di desain secara baik. Hal ini sejalan dengan pendapat Hidya Indasari (2016:6) yang menyebutkan bahwa booklet merupakan salah satu media cetak dalam bentuk ringkasan dan gambar yang manarik. Hal ini akan menjadikan booklet memiliki daya tarik tersendiri untuk memotivasi siswa untuk belajar. Booklet yang didesain dengan warna yang menarik, gambar dan tulisan yang ditata dengan seimbang, serta materi yang lebih ringkas dengan kata-kata dan kalimat yang jelas membuat booklet dapat dijadikan pilihan alternative media yang evektif dalam pembelajaran.

Berdasarkan hasil observasi yang dilakukan selama proses penyelesaian proyek booklet pembelajaran dengan authentic learning terlihat bahwa $100 \%$ mahasiswa aktif dalam mengerjakan proyek tersebut. Setiap mahasiswa memiliki tugas masing-masing yang harus dikerjakan dan diselesaikan guna memperoleh hasil proyek booklet pembelajaran yang memuaskan. Dengan authentic learning mahasiswa dituntut untuk aktif dan bertanggung jawab dalam menyelesaikan setiap bagian yang manjadi tugasnya dalam kelompok. Selain itu, mereka juga menjadi aktif berdiskusi apabila menemukan kendala, baik berdiskusi dalam kelompok, antar kelompok maupun diskusi bersama dosen. Berdasarkan hasil tersebut dapat disimpulkan bahwa dengan authentic learning manfaat yang diperoleh mahasiswa yaitu: 1) mahasiswa dapat belajar secara aktif; 2) mahasiswa memiliki 
pengalaman belajar secara berkelompok/tim dalam menyelesaikan proyek; 3) mahasiswa memiliki pengalaman belajar langsung dengan menghasilkan produk tertentu dimana produk tersebut dapat bermanfaat untuk pembelajarn siswa di sekolah; 4) mahasiswa dapat secara langsung terlibat dalam menyelesaikan tugas-tugas kompleks yang membutuhkan kemampuan berfikir tinggi, seperti menganalisis, sintesis, merancang, memanipulasi dan mengevaluasi informasi untuk dituangkan ke dalam proyek yang sedang dikerjakan; 5) mahasiswa dapat mengembangkan kemampuan bersosialisasi dan diskusi dalam tim maupun antar tim; 6) mahasiswa belajar disiplin dan bertanggung jawab terhadap tugas.

\section{SIMPULAN}

Berdasarkan penelitian yang telah dilakukan dapat disimpulkan bahwa authentic learning dalam pembelajaran produksi media cetak dapat berjalan dengan baik dan mampu memberikan pengalaman belajar yang nyata kepada mahasiswa yaitu dengan adanya proses pembuatan booklet pembelajaran. Manfaat yang diperoleh dari pelaksanaan pembelajaran authentic yaitu 1) mahasiswa dapat belajar secara aktif; 2) mahasiswa memiliki pengalaman belajar langsung/nyata; 3 ) mahasiswa memiliki pengalaman belajar dalam tim/kelompok; 4) mahasiswa dapat secara langsung terlibat dalam menyelesaikan tugastugas kompleks yang membutuhkan kemampuan berfikir tinggi; 5) mahasiswa dapat mengembangkan kemampuan bersosialisasi dan diskusi dalam tim maupun antar tim; 6) mahasiswa belajar disiplin dan bertanggung jawab terhadap tugas.

\section{DAFTAR PUSTAKA}

Audrey C. Rule. 2006. The Components of Authentic Learning. Journal of Authentic Learning. 3 (1):1-10. Edisi August 2006

Denhere Christmas. 2014. Authentic Pedagogy: Implications for Education. European Journal of Research and Reflection in Educational Sciences. 2 (4): ISSN 2056-5852

Endah R. Puji Astuti dan Muh Husein Baysha. 2017. Media Cetak Berbasis Project Based Learning. Jurnal Vi- sionary. 2 (1). Edisi April 2017. ISSN: 2503-4669

Larisa Nikitina. 2011. Creating an Authentic Learning Environment in The Foreign Language Classroom. International Journal of Instruction. 4(1). Edisi January 2011. E-ISSN: 13081470

Lexy J Moleong. 2010. Metodologi penelitian Kualitatif. Bandung: P.T. Remaja Rosdakarya.

Made Wena. 2013. Strategi Pembelajaran Inovatif Kontemporer Suatu Tinjauan Konseptual Operasional. PT Bumi Aksara: Jakarta. 